\title{
PELATIHAN SENI TEATER DI SURAKARTA : POTENSI, PERKEMBANGAN, DAN PENGELOLAAN
}

\author{
Akhyar Makaf \\ Jurusan Tari, Fakultas Seni Pertunjukan \\ Institut Seni Indonesia (ISI) Surakarta \\ Email : aku.makaf@gmail.com
}

\begin{abstract}
Theater Arts is widely taught in non-formal educational institutions such as studios, hermitage and extracurricular activities in formal schools. Its existence continues to grow as art education is realized to be an alternative media for the learning process. There came a number of Theater Arts training institutions in Surakarta. This research was conducted to examine the potential, development, and management of several training institutions that have a good reputation and have proven their presence in Surakarta. Qualitative research methods with analytic descriptive are used to analyze the training methods, curriculum, and management of training institutions that are used as research objects in order to see their potential and development. The results of this study can be used as a reference for anyone who is interested in developing non-formal educational institutions in the arts, especially Theater Arts. Based on this research, it can be concluded that the city of Surakarta as a City of Performing Arts, has the potential to be a location for the development of the Theater Arts training field. From the two objects of the training institution studied, the differences and variations in the training and management methods applied are described in accordance with the composition of the participants and the curriculum applied.
\end{abstract}

Key words: theater arts, non-formal education, training methods, management.

\section{Pendahuluan}

Sanggar merupakan $1 \mathrm{e} \mathrm{m} \mathrm{b}$ a g a pendidikan luar sekolah yang menunjang kegiatan kesenian untuk mengembangkan bakat dan minat seseorang dalam berkreasi (Rohayati,1998:2). Sanggar termasuk ke dalam lembaga pendidikan non-formal karena proses belajar terorganisir di luar sistem persekolahan atau pendidikan formal, baik dilaksanakan terpisah maupun merupakan bagian penting dari suatu kegiatan yang lebih besar yang dimaksudkan untuk melayani sasaran peserta didik tertentu dan belajarnya tertentu pula (Marzuki,2009:137).

Pendidikan non-formal dalam proses pembelajaran kesenian, dapat dilakukan melalui wadah-wadah organisiasi seperti padepokan, sanggar, lingkung seni, kursus kesenian, atau kegiatan ekstrakurikuler di sekolah formal. Dengan demikian usaha pelestarian kesenian dan kebudayaan dapat tetap tercapai dengan metode yang lebih fleksibel dibandingkan lembaga pendidikan formal. Lembaga pendidikan non-formal juga dapat menyusun materi pembelajaran yang sesuai dengan kebutuhan peserta dan ciri khas yang ingin ditonjolkan pengelolanya. Untuk lembaga pendidikan non-formal di bidang seni teater, terdapat beberapa jenis sanggar yang disesuaikan dengan kebutuhan anggotanya, salah satunya adalah sanggar teater anak.

Sanggar Teater Tanah Air yang diasuh oleh Jose Rizal Manua adalah contoh sanggar teater khusus anak yang memfokuskan proses 
kreatifnya untuk menciptakan pertunjukan bagi anak-anak. Selain itu juga terdapat Sanggar Ananda yang memiliki cabang di beberapa kota besar yang cukup diminati oleh anak-anak dan orang tua yang ingin mengasah potensi anaknya di bidang seni peran dan musik. Dua sanggar tersebut dapat dikatakan sebagai sanggar yang cukup serius dalam menciptakan pertunjukan teater bagi anak-anak. Di samping kedua sanggar tersebut, banyak terdapat sanggar-sanggar lainnya di berbagai kota besar dan daerah di seluruh Indonesia, baik yang dikelola secara profesional, atau lebih bersifat komunitas swadaya.

Sekolah sebagai lembaga pendidikan formal juga menjadikan kesenian sebagai salah satu ekstrakurikuler bagi siswanya. Penyelenggaraan ini memiliki beragam tujuan, sesuai dengan intensitas dan arah pendidikan di sekolah tersebut. Ada yang bertujuan untuk menjadikan seni sebagai media pembelajaran alternatif, pelengkap kurikulum utama, selingan dari aktivitas utama siswa, atau untuk tujuan meningkatkan prestasi sekolah dan media sosialisasi antar siswa. Tujuan ini menjadi alasan bermunculannya berbagai kegiatan ekstrakurikuler kesenian di sekolah-sekolah formal. Untuk proses pembelajarannya, pihak sekolah akan menyerahkan tanggung jawab ini kepada guru pengajar bidang studi kesenian, atau bekerja sama dengan pelatih yang didatangkan ke sekolah.

ISI Surakarta sebagai lembaga pendidikan seni yang bukan berorientasi pada ilmu kependidikan seni, akan lebih fokus pada proses pengajaran seni untuk menciptakan seniman yang memiliki ilmu pengetahuan dan pengalaman yang mumpuni. Di lembaga ini, tidak ada tuntutan bagi mahasiswanya untuk bisa menguasai ilmu dan teknik untuk menyampaikan ilmu itu kepada orang lain. Hal ini sesuai dengan format ISI Surakarta sebagai lembaga pendidikan yang lebih berorientasi pada penguasaan ilmu dan keahlian untuk diri sendiri dalam proses penciptaan karya seni dan penelitian seni.
Lulusan ISI Surakarta lebih dipersiapkan menjadi kreator dan ilmuwan di bidang seni, sesuai dengan kurikulum yang berlaku. Akan tetapi, pada kenyataannya banyak lulusan lembaga ini yang kemudian berprofesi di bidang pendidikan seperti dosen, guru, pendidik di lembaga pendidikan non-formal, pelatih, dan profesi pendidik lainnya. Tentu hal ini agak berbeda dengan tujuan lembaga ini, yaitu menciptakan seniman dan peneliti di bidang seni. Bukan berarti lulusan kampus seni non-kependidikan seperti ISI Surakarta tidak diperbolehkan menjalani profesi tersebut. Akan tetapi, tujuan dan kurikulum pendidikan di lembaga ini tidak menyiapkan lulusannya untuk menekuni profesi kependidikan seperti yang dijelaskan sebelumnya.

Program Studi Seni Teater ISI Surakarta memiliki tiga pilihan profil lulusan bagi mahasiswa yaitu minat Pemeranan, Penyutradaraan, dan Penelitian. Masing-masing minat disediakan bagi mahasiswa sesuai dengan kemampuan, keahlian, dan bakat yang akan dikembangkan. Selama menempuh perkuliahan, mahasiswa akan dibekali pengetahuan dan dituntut untuk melakukan praktik berkesenian sesuai dengan minat praktik yang mereka pilih. Untuk mahasiswa yang memilih minat penelitian (skripsi), mereka akan dibekali ilmu tentang pengkajian seni dan praktik melakukan penelitian.

Lulusan Program Studi Seni Teater ISI Surakarta, beberapa di antaranya memilih profesi sebagai pelatih seni di sekolah dan sanggar, di sela kegiatan berkesenian mereka. Dari beberapa pelatih, mereka berpendapat bahwa mereka memang kesulitan untuk menyiapkan dan menyampaikan materi secara efektif kepada peserta didik. Pada tahap awal, mereka seringkali memerlukan waktu dan penyesuaian materi tergantung kondisi dan tuntutan pihak sekolah atau sanggar. Mereka berpendapat, masalah ini mungkin bisa diatasi jika Prodi Teater ISI Surakarta menyiapkan materi pembelajaran dalam kurikulum yang menyasar pada kebutuhan akan materi kepelatihan teater untuk pendidikan 
non-formal.

Menyikapi fenomena ini, penulis memandang perlunya dibentuk laboratorium kepelatihan teater untuk mahasiswa Program Studi Seni Teater ISI Surakarta. Laboratorium ini berfungsi sebagai wadah mahasiswa untuk mempraktikkan, menguji, dan mengelaborasi ilmu yang sudah mereka dapatkan dalam perkuliahan, khususnya dalam hal aplikasi kepelatihan. Kegiatan kepelatihan ini akan menitikberatkan pada proses transfer ilmu yang telah mahasiswa miliki kepada orang lain yang membutuhkan. Dengan proses ini, diharapkan akan tercipta proses pembelajaran yang lebih efektif bagi mahasiswa dalam mempelajari keilmuan di bidang teater.

Lembaga pendidikan dan pelatihan seni yang penulis pilih adalah lembaga yang telah memiliki kemampuan dalam mengelola dan menjalankan misi kepelatihan dengan baik. Terlepas dari kelebihan dan kekurangan yang mereka hadapi di lapangan, tentu pengalaman dari pihak yang terlebih dahulu menyelenggarakan kegiatan ini dapat menjadi masukan yang berarti guna mendapatkan informasi yang komprehensif.

Setelah melakukan beberapa wawancara dan observasi awal, penulis mendapatkan informasi bahwa di Surakarta terdapat beberapa sanggar dan sekolah formal yang sudah cukup lama berkecimpung dalam kegiatan ini, sehingga lembaga-lembaga tersebut penulis pandang cukup layak untuk dijadikan objek penelitian ini. Lembaga tersebut adalah Sanggar Seni Kemasan Teater De Bocah (Surakarta) dan Ekstrakurikuler Drama SPA (Singapore Piaget Academy), Sukoharjo. Lembaga-lembaga tersebut penulis anggap sebagai lembaga yang menjalankan kepelatihan teater dengan manajemen yang baik dan telah berhasil mementaskan beberapa karya yang berhasil memenangkan penghargaan di kompetisi tingkat nasional. Karena alasan tersebut, penulis berkesimpulan bahwa kiprah lembaga tersebut dalam melakukan pelatihan layak untuk diteliti.

Penelitian ini akan menitikberatkan pada pengumpulan data yang relevan dengan kebutuhan untuk menelaah fenomena kepelatihan teater yang terselenggara dengan efektif secara manajerial dan memberikan metode pengajaran yang terstruktur. Salah satu indikator kefektifan ini adalah bahwa sanggar dan kegiatan ekstrakurikuler tersebut rutin menyelenggarakan latihan dan produksi untuk pementasan. Tolok ukur berikutnya adalah jika mereka mengikuti perlombaan, seringkali mendapatkan prestasi yang membanggakan baik di tingkat lokal maupun nasional.

Penelitan ini akan mencari data tentang metode pelatihan yang diterapkan, khususnya dalam pelatihan akting, tata artistik, penyutradaraan, penulisan naskah, dan lain-lain. Selain metode pelatihan, penulis akan melengkapi data dengan menggali informasi mengenai manajemen kepelatihan, manajemen produksi, dan pola proses kreatif secara kolektif yang diterapkan masing-masing lembaga pelatihan dalam membuat karya pertunjukan. Hal ini dilakukan untuk menjabarkan materi dan media pembelajaran yang digunakan lembaga-lembaga kepelatihan teater, guna mengetahui potensi lembaga kepelatihan teater Seni Teater di Surakarta. Mengetahui perkembangan lembaga lembaga-lembaga kepelatihan Seni Teater di Surakarta.

Hasil penelitian ini dapat digunakan sebagai salah satu bahan rujukan jika kelak rencana pembentukan laboratorium kepelatihan teater di Prodi Seni Teater direalisasikan.

\section{PEMBAHASAN}

\section{A. Potensi Pelatihan Seni di Kota Surakarta}

Surakarta sebagai salah satu pusat pelestarian seni dan budaya di Indonesia, memiliki banyak kelompok dan sanggar seni yang dikelola secara serius. Berdasarkan hasil pendataan 
Dinas Kebudayaan (Disbud) Surakarta pada tahun 2018 terdapat 172 kelompok seni yang terdaftar dan masih aktif menjalankan kegiatannya (Radar Solo, 21 Februari 2019). Salah satu bentuk sanggar adalah adalah sanggar seni yang melibatkan anak-anak sebagai peserta pelatihannya. Keaktifan beberapa sanggar anak-anak ini terlihat pada pelaksanaan kegiatan Festival Bocah Dolanan 2019 yang dilaksanakan pada tanggal 12 dan 13 Oktober dan diikuti oleh 20 sanggar anak (satu sanggar kemudian mengundurkan diri sebelum perlombaan).

Festival Bocah Dolanan y a $\mathrm{n} \mathrm{g}$ dilaksanakan pada tahun 2019 mengangkat tema "Melalui Festival Bocah Dolanan Kita Bentuk Karakter dan Budi Pekerti Luhur Generasi Muda Bangsa" menyajikan berbagai jenis permainan rakyat, khususnya permainan anakanak yang ada di Jawa Tengah dalam bentuk pertunjukan yang disajikan secara kreatif. Festival yang diadakan pada akhir pekan di tempat yang cukup strategis ini berhasil menarik minat banyak penonton. Selama dua hari berturut-turut, apresistor disuguhi pertunjukan yang dimainkan oleh anak-anak dari sembilan belas sanggar di Surakarta. Kemeriahan dan antusiasme peserta dan penonton Festival ini dapat dijadikan indikator yang menunjukkan geliat sanggar anak-anak yang cukup banyaknya jumlahnya di Surakarta, khususnya yang memiliki peserta didik usia sekitar 5 sampai 11 tahun.

\section{Sanggar Seni Kemasan}

Sanggar Seni Kemasan yang terletak di Jalan Mashella nomor 7 Kepatihan Kulon, didirikan oleh Bapak Bambang Sugiarto. Sebelum berubah nama menjadi Sanggar Seni Kemasan, sanggar tersebut bernama Sanggar Gidag Gidig yang didirikan pada 21 Desember 1976. Pada tahun 1984 Sanggar Gidag Gidig memilih tempat untuk dijadikan sanggar yang tetap, di lokasi yang saat ini diguanakan sebagai tempat latihan. Sanggar Gidag Gidig sempat kurang aktif selama 13 tahun. Kemudian akhirnya pada tahun 2013, sanggar ini kembali hadir dengan nama yang berbeda yaitu Sanggar Seni Kemasan. Sanggar Seni Kemasan dibuka untuk umum. Sanggar ini menerima anggota dari anakanak usia TK, SD, SMP, SMA, bahkan sampai mahasiswa. Pada awal didirikan, Sanggar Seni Kemasan dibuka dengan pertunjukan teater anak (Prasasti, 2:2016).

Sebagai sutradara dan penulis naskah dalam banyak pertunjukan di Sanggar Seni Kemasan, Bambang menerapkan metode, membuat peraturan dan kesepakatan bersama agar latihan berjalan kondusif. Beliau mengajari mereka dengan nilai-nilai yang sesuai dengan jiwa dan usia mereka. Bambang juga selalu memegang prinsip bahwa seni harus bermartabat, beretika, beradab, dan punya sopan-santun. Hal inilah yang kemudian menjadi pegangan bersama seluruh anggota sanggar dalam bersikap terhadap sesama anggota, pengurus sanggar, pelatih, orang yang lebih tua, pimpinan sanggar, orang tua, dan apresiator setiap pementasan.

Pimpinan sanggar dapat berperan sebagai pengelola di bidang manajemen sekaligus pengarah dalam eksplorasi artistik dan materi pelatihan. Peran di bidang eksplorasi artistik dan pelatihan, dapat dikatakan selayaknya tugas seorang guru. Hal ini sesuai dengan sebutan didaskalos (guru/pengajar, bahasa Yunani), bagi seorang dramawan di zaman Yunani Kuno. Sebutan ini disematkan karena peran seorang dramawan (penulis naskah/ sutradara) pada saat itu dianggap sebagai penyampai ilmu tentang kehidupan. Begitu juga dengan peran Bambang Sugiarto di Sanggar Seni Kemasan. Sebagai pelatih dan pimpinan di bidang artistik, dengan tanggung jawab mengarahkan dan membimbing anggota sanggar dalam menguasai dan mendalami seni, beliau dianggap sebagai guru selayaknya dalam proses pembelajaran. Hal ini sesuai dengan pendapat Trisanto $(1996: 182)$ yang menyatakan bahwa guru adalah orang yang berpengaruh dalam proses belajar mengajar, karena memiliki peran untuk 
membawa siswanya kepada tujuan yang ingin dicapai. Dengan tanggung jawab seperti itu, selayaknyalah guru memiliki pandangan luas dan otentik.

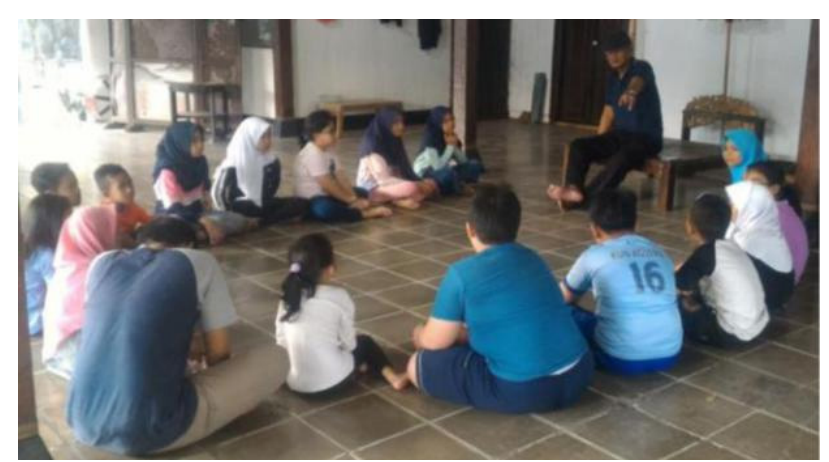

Gambar 1. Pemilihan peran dan aktor dari cerita yang telah disusun, langsung dilakukan oleh Bapak Bambang sebagai sutradara bersama Tarjo W. Kusumo sebagai pelatih untuk persiapan pementasan untuk persiapan Festival Bocah Dolanan 2019. Sumber foto : koleksi pribadi.

Trisanto (1996:182) juga menambahkan, bahwa siswa merupakan objek utama dalam proses belajar mengajar. Siswa dididik oleh pengalaman belajar mereka dan kualitas pendidikannya, tergantung pada kualitas pengalaman-pengalaman, dan sikap-sikapnya dalam pendidikan serta belajar dipengaruhi oleh orang yang dikaguminya. Metode praktik atau demonstrasi adalah melatih anggota dalam memahami pembelajaran sehubungan dengan metode latihan yang digunakan untuk menanamkan suatu keterampilan tertentu terhadap siswa dengan melakukannya secara berulang-ulang, sampai siswa itu mampu melakukannya secara otomatis.

Bambang juga menerapkan nilai-nilai moral tentang sopan-santun dalam proses latihannya. Misalnya, pada saat latihan mereka merasa tidak nyaman dengan blocking, dengan sopan mereka mengatakan kepada sutradara dan meminta untuk menggantinya. Dampak sopan-santun pun begitu terasa pada kehidupan mereka sehari-hari. Sebelumnya, anak-anak tersebut sering membantah ketika diberi nasihat oleh orang tuanya. Bahkan mereka berbicara kepada orang tua dengan nada yang membentak.
Melihat sikap anak-anak seperti itu, Bambang Sugiarto selaku penyadur naskah sekaligus asisten sutradara, tidak tinggal diam. Beliau memberikan nasihat kepada anak-anak, bagaimana seharusnya bersikap dan bertutur terhadap orang tua. Jiwa kebapakannya yang kuat membuat anak-anak pun mau mendengarkan dan menuruti nasihat beliau. Perlahan sikap anak-anak kepada orang tua mereka mulai berubah. Mereka mau mendengarkan nasihat orang tua, berbicara dengan nada yang rendah dan tidak membentak, dan mereka mulai menurut kepada orang tua (Prasasti,2016:110-111).

Bambang juga menambahkan bahwa kesenian yang sederhana (minimalis) boleh saja, tapi jangan asal-asalan. Ajari anggota sanggar (terutama anak-anak) dengan metode bermain dan bergembira. Proses berkesenian perlu menerapkan prinsip kebersamaan dan kompetisi sekaligus, serta harus dihadirkan secara utuh, untuk menunjang kreativitas mereka. Kreativitas ini diolah dalam proses latihan, dilakukan untuk pentas yang dijadwalkan secara rutin, sebagai target capaian dan media evaluasi dari proses latihan yang sudah dijalani.

Bambang berpendapat bahwa melibatkan anak-anak dalam pementasan, walaupun untuk peran kecil, adalah metode yang penting guna membangun rasa percaya diri mereka.

Usia anak-anak adalah masa-masa menyenangkan dan lebih banyak diisi dengan bermain. Tentu hal ini harus diperhatikan pelatih dalam menciptakan suasana latihan yang kondusif dan menyenangkan. Akan tetapi metode bermain sambil belajar ini memiliki resiko ketika porsi bermain menjadi dominan, sehingga membuat materi pelatihan menjadi terabaikan, atau membuat pelatih kewalahan menghadapi anak-anak. Pelatih menyiasati persoalan ini dengan menanamkan pada anak-anak anggota sanggar untuk tahu kapan waktunya serius dan kapan waktunya bersenda gurau (bermain-main). Pelatih perlu mengenali karakter dan kecenderungan anak (hasil wawancara, 29 
September 2019).

Metode pelatihan yang diterapkan memiliki kesesuaian dengan teori tentang faktor-faktor yang mempengaruhi pembelajaran (Syah, 1995:132) yaitu: (1) Faktor internal yang berasal dari dalam diri siswa, yang meliputi dua aspek, yaitu aspek fisiologis dan aspek psikologis. Pelatihan yang dilakukan terhadap anakanak usia di bawah 12 tahun, perlu memperhatikan metode dan materi pelatihan yang sesuai dengan perkembangan fisiologis dan psikologis mereka. Pendekatan improvisasi dan permainan adalah metode yang bisa mengakomodir tujuan ini. (2) Faktor eksternal atau faktor yang berasal dari luar diri siswa, yakni kondisi lingkungan di sekitar siswa, seperti halnya lingkungan sekolah, lingkungan keluarga dan lingkungan masyarakat. Peserta pelatihan dilatih untuk peka dengan lingkungan sekitarnya. Metode improvisasi yang dilakukan dalam proses pelatihan, selalu menggunakan pendekatan ini, dengan mengambil contoh permasalahan keseharian di sekitar anak-anak yang kemudian dijadikan cerita dan materi latihan. (3) Faktor pendekatan belajar (aproach to learning), yakni jenis upaya belajar siswa yang meliputi strategi dan metode yang ditemukan siswa, untuk melakukan kegiatan pembelajaran materi-materi pelajaran. Dalam hal penemuan ide, Bambang Sugiarto dan Tarjo W. Kusuma sebagai pelatih utama di Sanggar Seni Kemasan, memberikan kebebasan bagi anggota sanggar untuk menemukan sendiri cara belajar yang sesuai dengan kecenderungan masing-masing anak.

Dalam materi improvisasi dan penuangan ide, baik dalam proses pembuatan cerita, atau latihan peran yang akan dimainkan, metode ini menjadi salah satu alternatif, agar kreativitas dan keberanian anak-anak dapat terasah.

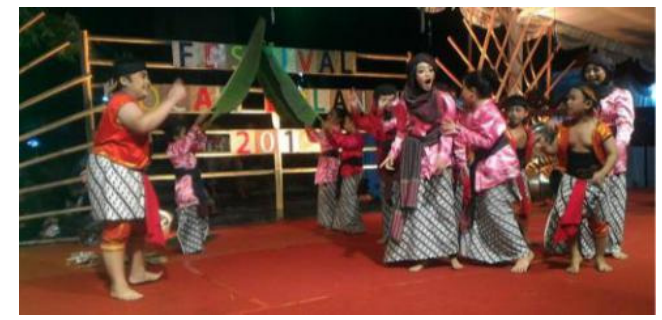

Gambar 2. Pementasan pertunjukan dengan judul "Latar Jembar" karya Bambang Sugiarto bersama anggota Sanggar Seni Kemasan dalam Festival Bocah Dolanan 2019 di Museum Radyapustaka, Surakarta. Sumber foto : koleksi peneliti.

UNESCO (United Nations Educational, Scientific and Cultural Organization) sebagai salah satu organisasi dunia yang intens membahas tentang permasalahan pendidikan mengemukakan teori tentang empat pilar pendidikan, yaitu :

1) belajar mengetahui (learning to know) yaitu pemerolehan instrumen untuk pemahaman, 2) belajar bekerja (learning to do) yaitu belajar secara kreatif dalam lingkungannya, 3) belajar dari dirinya sendiri (learning to be) untuk mengembangkan kepribadian, jati diri, dan tanggung jawab personal, dan 4) belajar hidup bersama (learning to live together) yaitu berpartisipasi dan bekerja sama dengan dengan individu atau masyarakat lain dalam berbagai kegiatan (Rustopo:2005). Jika dicermati dengan baik, dapat disimpulkan bahwa materi pelatihan dan prinsip pelatihan teater di Sanggar Seni Kemasan adalah penerapan yang cukup relevan dari keempat pilar pendidikan ini.

Kecerdasan Verbal-Linguistik: yaitu kemampuan yang berhubungan dengan kata/ bahasa tertulis maupun lisan. Anak-anak dilatih untuk berimprovisasi membuat cerita, baik secara lisan maupun tulisan, untuk kebutuhan proses latihan mingguan, persiapan pementasan bulanan, atau untuk perlombaan. Metode pelatihan ini terdiri dari dua varian bentuk. Metode pertama, pelatih sepenuhnya menyerahkan ide cerita kepada anak-anak, dan mereka akan melanjutkan dengan membuat penokohan, alur cerita dan dialognya secara utuh. Metode kedua, diawali dengan garis besar cerita yang sudah di- 
tentukan oleh pelatih, kemudian anak-anak akan dibebaskan untuk melengkapi cerita dengan dialog sesuai dengan imajinasi masing-masing. Kedua metode ini dapat dilakukan secara pribadi atau berkelompok, sesuai dengan kebutuhan. Metode ini adalah salah satu contoh pelatihan seni teater yang dapat digunakan $\mathrm{u} \mathrm{n} \mathrm{t} \mathrm{u} \mathrm{k}$ mengasah kemampuan verbal dan linguistik anak-anak.

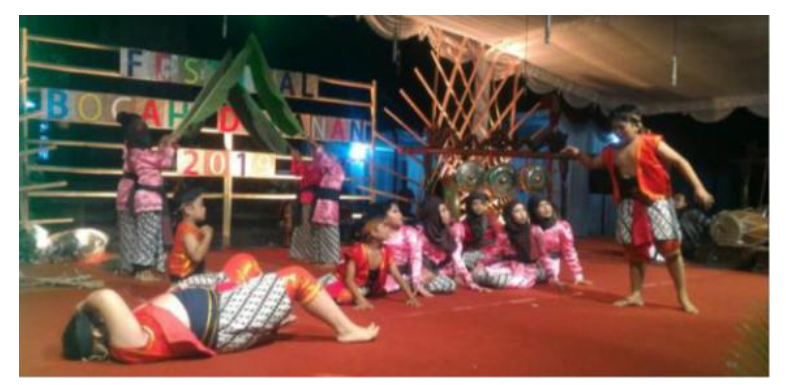

Gambar 3. Akting dan dialog yang diekspresikan oleh aktor dalam interaksinya di atas panggung adalah media yang efektif untuk mempertajam kecerdasan verbal (kata-kata), kecerdasan logika, kecerdasan tubuh, dan kecerdasan interpersonal anak-anak. Sumber foto : koleksi peneliti.

Kecerdasan Interpersonal: yaitu kemampuan berkomunikasi antar pribadi yang berhubungan dengan keterampilan berelasi dengan orang lain. Karena kerja teater adalah proses kolektif yang harus melibatkan orang lain, maka tidak dapat dielakkan bahwa untuk mewujudkan suatu bentuk pertunjukan, monolog sekalipun, relasi dengan orang lain adalah suatu keniscayaan. Dalam proses latihan di Sanggar Seni Kemasan, berlatih improvisasi dalam kelompok ketika membuat sebuah pertunjukan pendek seringkali digunakan dalam latihan mingguan. Proses ini akan memperlihatkan bagaimana proses interaksi secara alami antara sesama anak-anak dalam bekerja sama membuat cerita dan memerankannya menjadi sebuah pementasan mini.

Kecerdasan Fisik-Kinestetik : yaitu kemampuan mengatur gerakan badan dan memahami sesuatu berdasar gerakan. Dalam proses berlatih, kemampuan fisik dan kinestetik dituntut secara prima karena dalam pertunjukan teater, tubuh bagi seorang aktor adalah media ekspresi dan komunikasi yang penting selain kemampuan vokal dan verbal. Oleh sebab itu, materi olah tubuh menjadi salah satu materi pelatihan untuk meningkatkan kecerdasan kinestetik anak-anak, baik untuk kebutuhan estetika dan komunikasi pertunjukan juga untuk kebutuhan keseharian lainnya. Secara tidak langsung, dapat dilihat, bahwa melakukan pelatihan ketubuhan dalam berlatih teater dapat meningkatkan kecerdasan fisik dan kinestetik anak-anak.

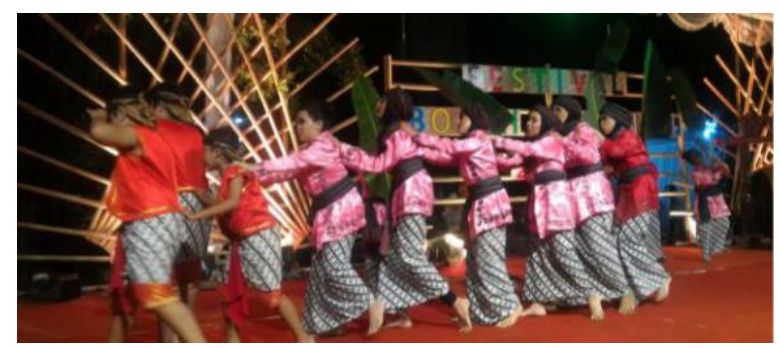

Gambar 4. Kerjasama antar sesama aktor adalah salah satu bagian penting dari pertunjukan teater. Selain untuk tujuan estetika pementasan, kerjasama yang dipraktekkan dalam pertunjukan dapat mengasah kepekaan sosial dan koordinasi fisik yang berperan penting bagi perkembangan kecerdasan Kinestetik, Interpersonal, dan visual-spasial bagi aktor. Sumber foto : koleksi peneliti.

Kecerdasan Musikal: yaitu kemampuan penalaran dan kepekaan terhadap suatu nada atau ritme. Musik adalah bagian dalam sebuah pertunjukan teater yang cukup penting. Musik dapat digunakan untuk berbagai kebutuhan. Bagi anak-anak yang akan memerankan tokoh dalam sebuah pementasan, musik dapat ia gunakan secara langsung dan tidak langsung. Kemampuan musikal digunakan secara langsung dalam pertunjukan ketika aktor perlu untuk mengatur tempo permainannya agar sesuai dengan tensi dramatik yang akan dimainkan. Begitu juga ketika pemain melakukan proses musikalisasi secara langsung dalam pertunjukan seperti dalam adegan nyanyian atau tembang, melagukan dialog, menciptakan irama permainan, dan melafalkan dialog dengan irama dan intonasi tertentu untuk kebutuhan dramatisasi. Secara tidak langsung, musik pertunjukan akan digunakan aktor untuk membantu menghadirkan mood permainan guna 
menciptakan atmosfir pertunjukan, terutama yang muncul dari proses pemeranannya. Pada bagian inilah proses berteater berhubungan erat dengan peningkatan kemampuan kecerdasan musikal pada anak-anak.

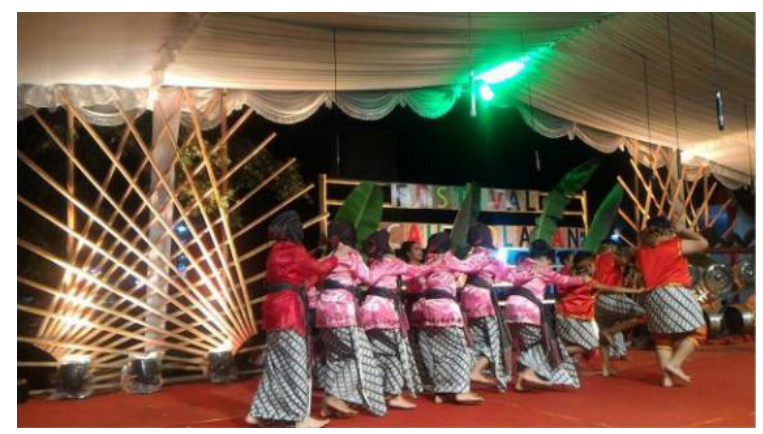

Gambar 5. Iringan musik, dialog yang dinyanyikan, dan tempo permainan dan harus diselaraskan dengan unsur musikal lainnya, dapat melatih kecerdasan fisik sekaligus kecerdasan musikal. Sumber foto : koleksi peneliti.

Kecerdasan Visual-Ruang-Spasial: yaitu kemampuan mengandalkan penglihatan, membayangkan objek dan menciptakan gambaran mental. Kemampuan anak-anak untuk menajamkan logika visual dan spasialnya dilatih ketika ia berimajinasi menciptakan ruang peristiwa dalam proses dramatisasi dari sebuah cerita. Dalam sebuah pertunjukan teater, peristiwa yang terjadi adalah sebuah rekayasa yang disadari oleh aktor dan penonton. Akan tetapi, aktor terus berusaha berimajinasi untuk menciptakan ilusi seolah-olah rekayasa di atas panggung itu adalah sebuah kenyataan. Salah satu imajinasi itu berhubungan dengan kemampuan mengkoordinasikan kecerdasan visual, ruang dan spasial, karena dalam pertunjukan, terdapat imajinasi ruang, tempat, dan waktu yang berbeda dengan realita. Selain itu, penataan artistik, properti, dan unsur artistiknya yang harus direspon secara kreatif oleh pemain, adalah proses latihan yang menantang yang harus dilakukan oleh anak-anak anggota sanggar. Begitu juga dengan kemampuan anak-anak dalam menguasai tubuhnya dalam penataan blocking di atas panggung, berkoordinasi dengan pemain lain, menciptakan konfigurasi, mengatur gerak dan langkah di area panggung, merespon benda-ben- da, dan sebagainya, adalah proses berlatih untuk meningkatkan kemampuan visual, ruang, dan spasial mereka.

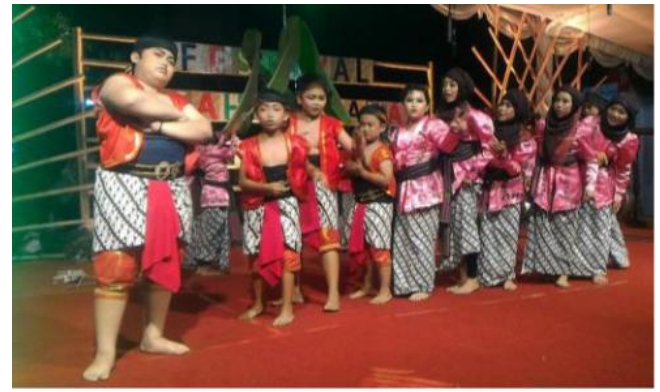

Gambar 6. Kerjasama antar sesama aktor adalah salah satu bagian penting dari pertunjukan teater dan dapat mengasah kepekaan sosial dan koordinasi fisik yang berperan penting bagi perkembangan kecerdasan Kinestetik, Interpersonal, kecerdasan Intrapersonal dan visual-spasial bagi aktor. Sumber foto : koleksi peneliti.

Proses berlatih teater juga dapat ditinjau berdasarkan teori yang menjelaskan pembagian kerja otak manusia berdasarkan pembagian otak bagian kiri dan bagian kanan. Ditemukan bahwa sebagian besar kegiatan kecerdasan logis-matematis dan kecerdasan verbal bahasa dilakukan di belahan otak kiri. Sedangkan kegiatan kecerdasan lainnya dilakukan pada otak kanan (intrapersonal, interpersonal, visual-ruang, gerak-badan, dan musik-ritme). Pink (2008:43) menjelaskan bahwa belahan otak kiri memperhatikan logika, urutan, literal, fungsional, kata-kata, tekstual, dan analisis. Sedangkan belahan otak kanan peduli terhadap sintesis, ekspresi, emosional, konteks, simultan, metaforis, estetis, dan keseluruhan perspektif. Berdasarkan teori ini dapat disimpulkan bahwa penting dalam dunia pendidikan untuk menciptakan proses pembelajaran dan pendidikan yang mengembangkan aktivitas otak kanan maupun otak kiri demi mengembangkan semua aspek kemanusiaan perseorangan.

Metode pelatihan teater yang sudah dijelaskan sebelumnya, dapat menjadi contoh bagaimana mempraktikkan proses pembelajaran yang dapat mengasah kemampuan otak kiri dan otak kanan secara seimbang. Kemampuan verbal 
dalam memproduksi kata-kata, logika dalam menganalisis cerita, menghafal dialog, mengingat tanda (clue), mengingat pembagian adegan, dan sebagainya, adalah proses otak kiri yang berlangsung pada pemain. Begitu juga pada saat aktor memproduksi ekspresi, menciptakan rekayasa emosi, membuat metafora melalui kata atau visual, perspektif dan proses estetis lainnya. Bagian ini adalah proses kerja yang lebih banyak terjadi di belahan otak kanan. Oleh sebab itu dapat disimpulkan, bahwa dalam proses berlatih teater, tercipta keseimbangan dalam menstimulasi kedua bagian otak secara efektif.

Lebih lanjut Pink (2008:93-96) juga menjelaskan tentang enam kecerdasan penting yang diarahkan oleh otak kanan, yaitu : 1) tidak hanya "fungsi" tetapi juga "desain", 2) tidak hanya "argumen" namun juga "cerita", 3) tidak hanya "fokus" tetapi juga "simfoni", 4) tidak hanya "logika" tetapi juga "empati", 5) tidak hanya "keseriusan" tetapi juga "permainan", 6) tidak hanya "akumulasi" tetapi juga "makna". Dari enam elemen kecerdasan yang diproses di bagian otak kanan tersebut, seluruhnya dapat dilatih melalui latihan teater yang menggabungkan berbagai bentuk kesenian dan potensi. Hal ini dapat terwujud karena seni teater adalah penggabunggan dari seni bercerita, seni musik, desain, permainan secara fisik dan emosi, bersifat logis sekaligus empatis, dalam menyampaikan sebuah makna dari kehidupan. Marianto (2007) menambahkan bahwa belahan otak kanan adalah bagian untuk berfikir melalui metafora dan simbol, humor, estetika, berfikir melingkar, holistik, non-linear, melihat pola secara keseluruhan, berfikir dengan visualisasi dan imajinasi, mempersepsi kedalaman dan emosi, responsif, reaktif dan intuitif.

\section{Kelas Drama Sekolah Singapore Piaget Academy (SPA)}

Kelas drama di Sekolah Singapore Piaget Academy (SPA) diajarkan mulai dari tingkat 3, 4, dan 5 Materi yang diajarkan adalah materi-materi teater dasar. Materi pelatihan di kelas 3, misalnya, menggunakan teknik pelatihan metode cermin; siswa menirukan gerakan temannya, seolah-olah mereka sedang bercermin. Motede ini cukup efektif dan dianggap menyenangkan bagi para siswa. Akan tetapi metode kurang efektif diterapkan pada siswa kelas 4 ke atas. Hal ini dikarenakan secara usia mereka sudah merasa dewasa dan sedikit enggan untuk melakukan metode pelatihan yang terlalu elementer. Pelatih kemudian menyiasati dengan melakukan pelatihan metode imajinasi bentuk dari benda keseharian yang mudah ditirukan dengan formasi berkelompok.

Materi pelatihan berikutnya adalah pelatihan dasar seperti oleh tubuh, lari keliling lapangan, dan pelatihan olah vokal. Ternyata materi ini juga kurang diminati oleh siswa. Setelah diajak berdiskusi, ternyata mereka lebih tertarik untuk langsung praktik berlatih pemeranan. Akhirnya pelatih menyiasati materi latihan dengan merubah metode dengan berlatih pemeranan dengan menggunakan cerita mini. Dalam proses ini pelatih menyiasati pembelajaran dengan metode berlatih pemeranan secara langsung, sambil disisipi materi praktik dan teori dasar pemeranan yang lebih praktis. Metode ini lebih efektif digunakan pada siswa yang lebih tertarik pada praktik pemeranan melalui contoh langsung, daripada materi pemeranan secara runut berdasarkan elemen-elemen pembentuknya (gerak, vokal, ekspresi, tempo, dan lainlain). oleh karena itu, kreativitas pelatih dalam menghadapi peserta didik yang berbeda-beda perlu dilatih untuk menghadapi berbagai kemungkinan yang terjadi dalam proses latihan (hasil wawancara dengan Luna Kharisma tanggal 10 Sepetember 2019).

Metode awal yang penting pada proses latihan yang dilakukan pelatih di kelas drama SPA adalah proses melihat dan meniru dari adegan yang dicontohkan. Dapat dikatakan bahwa ini adalah sebuah proses simulasi sederhana dari pelatih di tahap awal kepada peserta didik. Selain melalui contoh langsung, siswa juga ditawarkan untuk melakukan observasi dari 
adegan-adegan film yang disajikan. Adegan film yang dipilih adalah scene-scene penting yang memperlihatkan ekspresi dari aktornya secara detail. Menurut Luna, metode observasi ini lebih efektif, walaupun berisiko akan menciptakan streotipe dan kurang menantang kreativitas. Hal ini juga terkendala dengan adanya perbedaan antara gaya akting dalam film dan gaya akting untuk kebutuhan panggung. Oleh sebab itu, pelatih harus memberi memberi conto h secara langsung kaidah-kaidah pemeranan yang sesuai dengan kebutuhan pertunjukan di atas panggung. Selain dari objek film, siswa juga diminta untuk melakukan pengamatan di lingkungan sekitarnya, seperti mengamati tipe-tipe orang yang ada di sekitar, di sekolah, keluarga, dan lain sebagainya.

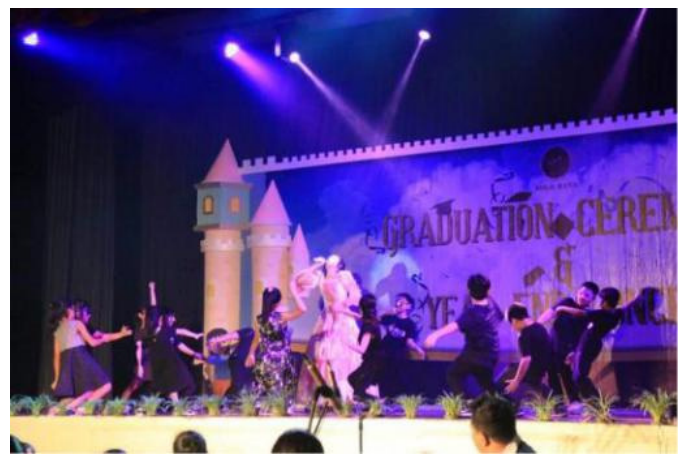

Gambar 7. Konfigurasi gerak kreatif dalam pertunjukan siswa Singapore Piaget Academy (SPA), Solo Baru. Sumber foto : koleksi Luna Kharisma.

Pelatih juga menerapkan prinsip bahwa ia harus menganggap sama bagi semua peserta didik, walaupun terdapat perbedaan kemampuan dan ketertarikan masing-masing siswa terhadap materi drama. Hal ini berguna untuk meningkatkan motivasi peserta didik yang kurang memiliki minat atau belum mampu menguasai materi. Selain itu, metode ini juga penting untuk menciptakan atmosfir agar semua peserta tetap bersemangat berlatih dan berusaha untuk menguasai materi, tanpa perlu bergantung kepada kemampuan peserta yang lebih cepat memahami materi dan dorongan dari pelatih. Bahkan seringkali pelatih memberikan kepercayaan lebih banyak kepada peserta yang kurang berbakat, untuk memotivasinya agar berusaha lebih giat untuk menguasai materi. Pada akhirnya, untuk kebutuhan pementasan, pelatih tidak selalu memilih pemain terbaik menjadi pemeran utama, untuk memberi kesempatan kepada siswa yang berkemampuan biasa untuk menempa dirinya menjalankan tugas menjadi pemeran utama yang dipercayakan kepadanya.

Selain menekankan pada kemampuan pemeranan, penguasaan materi berikutnya adalah hafalan dialog. Mereka seringkali terkendala mengucapkan dialog secara baik dan benar karena lupa, salah intonasi, dan kurang kuat memperlihatkan motivasi. Hal ini dapat diatasi salah satunya dengan mengajak mereka berdiskusi ketika melakukan bedah naskah untuk menumbuhkan dan meningkatkan pemahaman siswa terhadap dialog, motivasi tokoh, dan struktur dramatik dari cerita yang dipresentasikan.

Luna juga memperhatikan kemampuan blocking (penempatan dan pemosisian pemain di atas panggung) dalam latihan persiapan untuk pementasan. Hal ini dilakukan karena secara umum, siswa-siswa yang masih awam dengan dunia teater masih agak kesulitan memahami materi ini. Siswa-siswi SPA yang cenderung kritis dan rasional, diberikan kesempatan untuk memberi tawaran metode dan solusi alternatif jika mereka menemukan kendala dalam proses latihan. Mereka merasa senang jika diajak berdiskusi untuk mencari solusi bersama. Metode ini efektif untuk melibatkan mereka secara emosional dengan proses penggarapan pertunjukan yang sedang berlangsung.

Kendala berikutnya yang ditemukan dalam proses latihan adalah volume vokal mereka yang kurang jelas dan kurang lantang. Hal ini terjadi karena mereka belum terbiasa untuk berbicara dengan volume tinggi. Untuk mengatasi masalah ini, Luna melatih mereka untuk mencoba memproduksi suara dua kali lebih lantang dari pada suara biasanya yang mereka gunakan sehari-hari. 


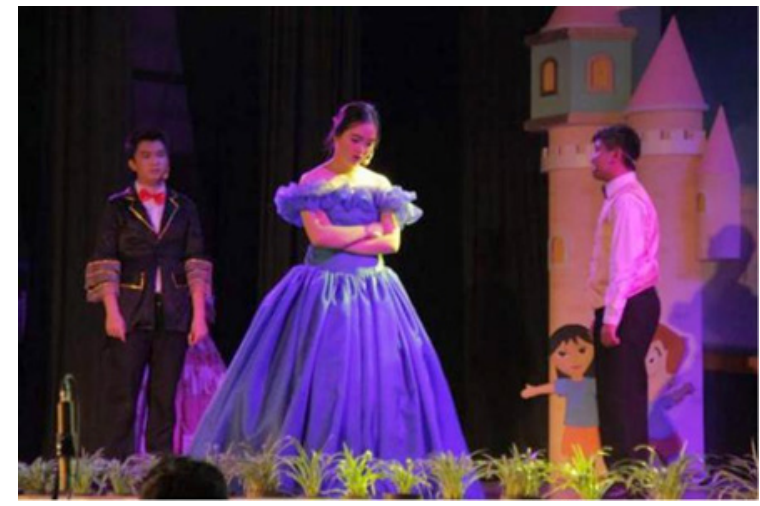

Gambar 9. Salah satu adegan dalam pementasan "Romeo and Juliet" oleh siswa Singapore Piaget Academy. Sumber Foto : koleksi Luna Kharisma.

Metode berikutnya yang digunakan untuk mempermudah mereka menghafal dialog dan adegan adalah dengan menggunakan musik sebagai tanda (clue). Karena siswa sudah cukup akrab dengan apresiasi musik, sehingga metode ini sangat membantu mereka dalam menguasai materi pemeranan dan blocking. Kemampuan musikalitas mereka yang cukup baik bisa membantu mereka untuk mengingat dialog, pembagian adegan, ingatan emosi di setiap adegan, dan lain-lain. Selama proses ini berlangsung, siswa juga terus diberi tantangan agar proses latihan tetap menyenangkan. Luna terus memberi dukungan pada siswa yang menunjukkan keseriusan dan usaha yang lebih dalam menguasai materi. Pada posisi inilah peran pelatih sebagai penjaga pengendali kondusifitas latihan diperlukan (hasil wawancara dengan Luna Kharisma tanggal 21 Oktober 2019).

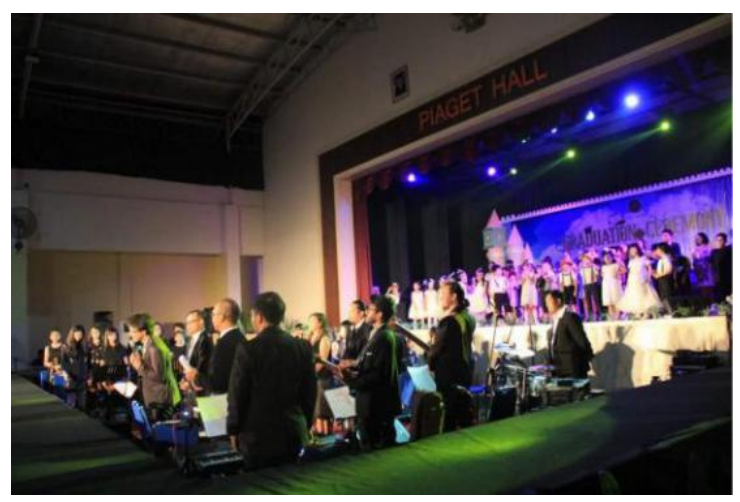

Gambar 10. Pertunjukan rutin Year End Concert yang menampilkan pementasan teater hasil pelatihan pada Kelas Drama dari berbagai tingkatan. Foto : koleksi Luna Kharisma.
Selama tiga tahun melatih, Luna melihat telah terjadi beberapa perubahan yang lebih positif. Beberapa dari mereka sudah bisa membuat naskah sendiri. Setelah beberapa kali mengikuti Year End Concert pelatih dan guru-guru dapat dilihat perkembangan kemampuan siswa, khususnya dalam mempraktikkan seni peran. Sudah cukup banyak siswa-siswi SPA yang lebih percaya diri dalam berekspresi di atas panggung.

\section{KEPUSTAKAAN}

Armstrong, Thomas. 1996. Multiple Intelligences in The Classroom. Virginia : Association for Supervision and Curriculum Development.

Darsono, Max, dkk. 2000. Belajar dan Pembe lajaran. Semarang: CV. IKIP Semarang.

Gardner, Howard. 1983. Frames of Mind: The Theory Of Multiple Intelligences. New York. Basic Books.

Gardner, Howard. 1993. Multiple Intelligences : The Theory in Practice A Reader. New York : Basic Books.

Goleman, Daniel. 2003. Kecerdasan Emosional, terjemahan : T.Hermaya. Jakarta. Gramedia Pustaka Utama.

Lickona,Thomas. 2004. Pendidikan Karakter. Bantul, Kreasi Wacana.

Marianto, M. Dwi. 2007. Relasi Luar-Dalam Antara Seni Dan Metafora. Jurnal Penciptaan Dan Penciptaan Seni tahun 2007. Pascasarjana ISI Yogyakarta.

Pink, Daniel. H. 2008. Misteri Otak Kanan Manusia. Yogyakarta. Think.

Prasasti, Birgitta Ciptaning Sri. 2014. Pementasan Dalang dan Wayang. Skripsi Prodi Seni Teater. ISI Surakarta. 
Arintya Jurnal Penelitian Seni Budaya

Ratna, Nyoman Kutha. 2010. Metodologi Penelitian. Kajian Ilmu Budaya dan Ilmu Sosial Humaniora Pada Umumnya. Yogyakarta. Pustaka Pelajar.

Rustopo, Bambang Murtiyoso (ed). 2005. Mencermati Seni Pertunjukan III Per spektif Pendidikan, Ekonomi \& Manajeman, dan Media. Surakarta. PPs STSI Surakarta. 